\title{
Meet the candidates for ALA President
}

\author{
Vote in the election this spring
}

by Carla D. Hayden and Katina Strauch

$\mathrm{T}$ he ACRL Board of Directors posed the following questions to the candidates for ALA President, and CERL News is pleased to publish their responses. Each candidate was given 1,200 words in which she could choose to offer a brief opening statement and to respond to the questions; the responses are identified under each of the six questions.

\section{Opening statement}

Carla D. Hayden: My professional experiences include being a paraprofessional, children's librarian and young adult services coordinator, a special librarian in a science museum, an assistant professor in a library school, and an administrator in two urban library systems with major research capacities and responsibilities. I have broad experience in providing resources for the lifelong learner, serving the different needs of people of all ages and backgrounds, protecting intellectual freedom, the right to information and the privacy of the user, and preserving the record of human knowledge.

Throughout these varied experiences, I have found that there is much more that unites us than divides us as a profession. No matter with what type of library we are affiliated, our core values should be maintained and strengthened in the future. Affirming our core values, recognizing our realities, and assuring our future are the basic commitments on which I would be honored to work with you as ALA President.

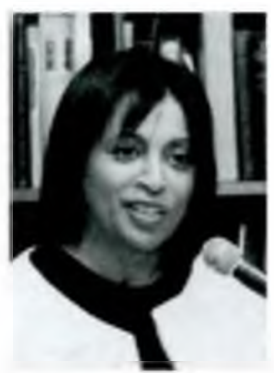

Carla D. Hayden

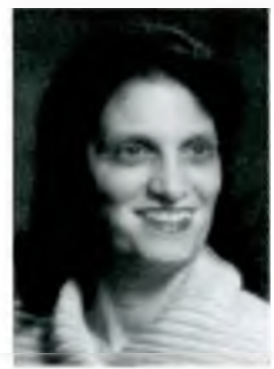

Katina Strauch

\section{Questions for ALA candidates}

1. What are the two most important issues that will assure the strength of our profession in the future? What ideas do you have to address these issues as ALA President?

Hayden: The two most important issues that will assure the strength of our profession in the future are the needs for increased recruitment and retention. We need to increase the visibility of our profession as an attractive and exciting career choice. As chair of the Committee on Accreditation and the Spectrum Initiative, I became acutely aware of the need to engage youth as soon as possible in the profession and make targeted, sustained efforts to attract people from underrepresented groups. As a manager, I have initiated a succession-planning program with men toring, job shadowing, leadership development training, and support for conference attendance and professional involvement, and

\section{About the authors}

Carla D. Hayden is executive director of the Enoch Pratt Free Library, e-mail: chayden@mail.pratt.lib.md.us, and Katina Strauch is head of collection development at the College of Charleston Libraries, e-mail: strauchk@cofc.edu 
increased promotion opportunities within position categories. As ALA President, I would continue to support these types of activities throughout the profession. The status of librarians is key to the future of all types of libraries. As an administrator, I continue to work for pay equity, competitive benefits, and an improved working environment. I would continue to support these issues, particularly the recent initiative by President Mitch Freedman.

Strauch: By 2009, 25 percent of us are expected to retire. We must recruit and train a new generation of more diverse, skilled, and committed librarians. As president, I will work to continue the work of Mitch Freedman's Task Force on Pay Equity and appoint a second task force on the Emerging Roles of Librarians in the 21st Century.

We need to adjust and adapt to competition from the commercial sector. For the first time, libraries and librarians are encountering business people who want to get in on what we do best. Libraries and librarians have to become more market-savvy, more active, more self-assured, and perhaps more focused than we have been in the past. The profession has changed as the world around us has changed. Librarians should be-and areleaders in locating, accessing, and organizing information regardless of its format. I believe that ALA needs more input from the grassroots, practicing librarian. As president, I will solicit your help. I would appreciate your input now at my Web site at http://www. katina.info.

\section{Academic and research libraries and librarians are not highly visible in ALA publicity, materials, and advocacy efforts. What will you do to generate more knowl- edge and appreciation of the role aca- demic librarians play in advancing re- search, education, and civic and eco- nomic development?}

Hayden: I would support the continuation of ALA's media campaigns that raise public awareness of the important role all libraries and librarians can and do play in community and economic development. We are all part of the information-seeking continuum. In many cases we serve the same customers as they move from " $K$ to Grey."

As president, I would make sure that academic librarians' contributions are also fea- tured prominently in promotional materials and advocacy efforts. The public needs to recognize the special contributions of academic librarians in their daily lives. From community colleges retooling and retaining our workforce to working hand-and-hand with public libraries, especially in many rural areas, academic librarians not only contribute to advanced research and exploration but also help create a comprehensive learning community across the nation.

Strauch: I am an academic librarian and have been for more than 20 years. I agree that academic librarians are not visible in ALA publicity, materials, and advocacy efforts. There is too much apathy in the profession, particularly among academic librarians. I want to do my best to change that. I am a frontline, practicing academic librarian. Academic librarians need more of a voice on ALA Council, on ALA Executive Board, and in American Libraries. But, first, academic librarians must vote and make their voices heard. Do you know that less than 7 percent of the membership voted in last year's presidential election? There are more than 65,000 members in ALA!

As president, I will work to make the ALA balloting more straightforward. We are all busy people and the current voting system is cumbersome and somewhat of a mystery. I want to change all this, at least by making more information available on the entire voting process and procedure and making it easier to vote. I am not holding myself up as a paragon. Many is the time I have not voted in ALA elections. We must change this phenomenon together.

3. A majority of librarians are not members of ALA. Is ALA relevant and vital to librarians? How can ALA position itself to provide compelling relevancy to the profession in a different future?

Hayden: As we face challenging times, ALA can be even more responsive to members' needs and concerns, while continuing its advocacy role. At approximately 63,000 members, ALA has almost half of the estimated 150,000 librarians in the United States as members. I know that for many the price of membership, excluding divisions, is beyond the reach of those with an average salary and no institutional support, especially support staff. 
I face many of the issues of our

profession daily, not as theory or

supposition, but as hard realities

that require sound decision making

and consensus building. As

president, I would work for more

inclusion of diverse groups and

views, while providing a positive

force for change and continuity.

-Carla D. Hayden

My experiences as a member for more than 22 years have helped shape my career and contributed significantly to my professional and personal development. Leadership development can be shared with chapters, divisions, and other associations. We can all work together to improve communications and increase membership. Part of that effort must include demonstrated interest in the real needs of frontline librarians and administrators in all types of libraries. That knowledge can then be used to create more relevant and timely materials, programs, and regional workshops

Strauch: I have seen figures that estimate that there are more than 140,000 librarians in the United States. This means that ALA has barely 46 percent of the librarian population as members. In running for president, I have talked to a lot of people. I would say that, easily, half of them are not ALA members, yet they work in the profession in some sort of library-related job. They have many reasons which sound valid for the situation. But ALA is a membership organization. It is not an amorphous "they" out there. ALA is you and me. If ALA is not providing relevancy to the profession, it is because we are either not speaking up or not being heard. If you are not a member of ALA, why? What can we change to make you want to be a member? If you are a member of ALA but are thinking of not renewing your membership, what can we do to make you want to rejoin? And the "we" in this situation is you and I, not ALA.

I think the profession is at a crossroads. I believe passionately in information lit- eracy, the importance of archiving electronic information, the value of librarianship as a profession, and the new library as the community information center. But we are being assailed from many sides. We must work together to make ALA speak for us.

4. As ALA President, you will preside over ALA Council. How can Council best spend its time together in the best interests of the association? What issues are and are not appropriate for Council discussion and debate?

Hayden: The Council has an important role in initiating and promoting issues for the association and membership to address. These include all matters, foreign and domestic, that could affect the future of libraries and the information professions. We need unity yet must respect differences of opinion as we come together to safeguard our values. This is even more important now as we face many complex and challenging issues. Council should ensure that process and personal agendas do not complicate the real need to address issues, such as cyberlegislation and threats to user privacy. As the presiding officer at council meetings, I will make sure the discussions remain civil and focused.

Strauch: Talk about a loaded question! I'll be honest. I had never been to an ALA Council meeting before I was asked to run for president in November 2001. At ALA Midwinter in New Orleans, I was asked to attend some Council meetings and was also immediately made a member of the ALA Council electronic list. Surprisingly, I have been really impressed by ALA Council, its members, and its deliberations. ALA Council, believe me as an outsider, is an incredibly committed group of men and women. They care deeply for the profession and for ALA. Yes, in my opinion and many of yours, they do debate some issues that we consider outside of the purview of a group of professional librarians.

As ALA President, I would do my best to confine discussions to real librarian and library issues. But we live in a democratic society, thank goodness, and we have to adhere to the wishes of the majority. This is why we all need to become more active in ALA. 
5. What are the appropriate roles of corporate and individual donor sponsorships in the success of ALA? How are these partnerships best developed, maintained, and nurtured?

Hayden: Corporate and individual donors can be significant contributors to the mission and programs of ALA, particularly in media campaigns and scholarship opportunities. By giving companies and individuals the ability to partner with us, we increase our capacity to reach our goals. As with any fundraising effort, all partnerships should be made with a clear understanding between the parties regarding appropriate activities and expectations. Although gifts may be substantial, especially by some individuals, ALA must safeguard its mission and values at all times. The relationships can be maintained and nurtured by careful and sensitive stewardship. Extensive communication with the donor and inclusion in some aspects of program development and implementation are essential to nurturing our relationships.

Strauch: Obviously, corporate and individual donors play a role in ALA. I was looking at the ALA 1999/2000 annual report the other night. About 4 percent (nearly a million dollars) of ALA's budget comes from donations and contributions. As a person who founded and has sustained the Charleston Conference for more than 21 years, I know the importance of donations in maintaining the budget of a nonprofit entity. As you say, it's a partnership. Corporate and individual donors must feel, not resentment at being asked for money, but camaraderie for the good of the order. I have a strong relationship with many academic librarians, scholarly publishers, and vendors of library materials. We are all in this together. We need to work as partners to make our world viable in the 21 st century

6. What knowledge, experience, and skills do you bring to the position of ALA President? How will you provide leadership to the members and facilitate progress in meeting the goals of the association? Is there a particular initiative you want to pursue in support of the ALA strategic plan? What do you hope to have accomplished by the end of your presidency?

\section{But ALA is a membership}

organization. It is not an

amorphous "they" out there. ALA

is you and me. If ALA is not

providing relevancy to the

profession, it is because we are

either not speaking up or not

being heard.-Katina Strauch

Hayden: During my career I have been on the frontlines, in library and nonlibrary boardrooms, in political arenas, appointed by ALA Past-Presidents to serve on and chair numerous committees and task forces, taught at four library schools, written on library issues, and made national and international presentations. My experiences prepare me to address the concerns of membership and be an effective advocate for the profession and libraries. I face many of the issues of our profession daily, not as theory or supposition, but as hard realities that require sound decision making and consensus building.

As president, I would work for more inclusion of diverse groups and views, while providing a positive force for change and continuity. ALA Action 2005 contains two initiatives that I would like to concentrate on during my presidency: a) developing a model for 21st-century library practice encompassing all formats, all people, all means of delivery, and all types and sizes of libraries, and b) that all ALA members will have a broad range of service and product choices (including electronic) to support their needs. By the end of my presidency, I hope to have provided leadership in increased inclusion and choice for the membership, with progress being made on informing the public of our value and setting the groundwork for defining the library of the future.

Strauch: People who know me describe me as a high-energy and creative person. They call me an innovator, a risktaker, a mentor, and a role model. I like to make things happen and bring people together to discuss issues and build coalitions. That's 


\section{ACRL members running for ALA Council}

The following ACRL members are either nominated or petition candidates for ALA coun1 cilor in the spring 2002 elections. ACRL members are encouraged to vote for these candidates to increase ACRL's voice in ALA's affairs.

Gladys Smiley Bell, assistant director of public services, Harvey Library, Hamp ton University

Herbert Biblo, Long Island Library Resources Council

Frank A. Bruno, library director, Prairie View A\&M University

John E. Buschman, professor/librarian, Rider University Library

Tara L. Dirst, technology coordinator/ Lincoln Digitization Project, Northern I1linois University

David Easterbrook, curator, Melville J. Herskovits Library of African Studies, Northwestern University Library

Bradford Eden, head of bibliographic and metadata services, University of Nevada, Las Vegas

Debra H. Engel, director of public services, Bizzell Libtary, University of Oklahoma

Edward Erazo, head of reference and instructional services, Florida International University

John W. Forys Jr., head, Engineering Library, University of Iowa

Bernard Fradkin, dean of learning resources, College of DuPage Library

Fred Gertler, head of customer services, Santa Clara University

Linda Marie Golian, university librarian/reference team leader, Florida Gulf Coast University Library

Michael Gorman, dean of library services, California State University

Roland C. Hansen, head of access services, Columbia College Library

Heidi Lee Hoerman, instructor, University of South Carolina, College of Library and Information Science

Juliana G. (Julie) Huiskamp, coordinator of learning resources, Northeast Iowa Community College

Charlene S. Hurt, university librarian, Georgia State University

John G. Jaffe, director of libraries and integrated learning resources, Sweet Briar College
Joyce E. Jelks, acquisitions reference librarian, Auburn Avenue Research Library on African-American Culture and History

Robert Klassen, consultant, Washington, D.C.

Kathleen L. Kluegel, reference librarian and networked resources coordinator for reference, University of Illinois at $\mathrm{Ur}$ bana-Champaign

Leslie Kong, head of library public services, California State University, San Bernardino

Amy E. Mark, head of library instruction, John Davis Williams Library, University of Mississippi

Peter McDonald, associate university librarian for collection development, Syracuse University

Laurel Minott, assistant university librarian for public services, Northwestern University Library

Paula Murphy, research services librarian, Chicago Historical Society Library

Susanna Bartmann Pathak, planning and assessment librarian, Virginia Commonwealth University Libraries

Veronda J. Pitchford, coordinator of membership services and special projects, Chicago Library System

Robert Ridinger, chair of electronic information resources management, Founders Memorial Library, Northern Illinois University

Jordan M. Scepanski, executive director, Triangle Research Libraries Network

Peggy Seiden, director of libraries, Swarthmore College

Karolyn S. Thompson, professor/interlibrary loan coordinator, University of Southern Mississippi

Mark R. Watson, associate university librarian for technical services, University of Oregon

Barbara J. Wittkopf, reference/instruction librarian, Louisiana State University Libraries 
why more than 21 years ago I founded the Charleston Conference, an informal and noncommercial annual meeting for publishers, vendors, and librarians, called "the most intelligent, provocative and useful of library conferences," and a few years later published Against the Grain, a journal linking publishers, vendors, and librarians, which Bill Katz has said is a "must have journal for anyone involved in publishing and/or library acquisitions work."

In 1999, with Becky Lenzini, George Machovec, Chuck Hamaker, and many others, I began The Charleston Advisor, an electronic and print publication that reviews electronic products offered to the library marketplace.

I think of myself more as a facilitator than a leader. I try to observe what's happening and persuade people to talk about what they think about specific issues. I believe that the best solutions come about through collaboration and open communication. I believe strongly that we need more of a blueprint for the librarian and libraries of the 21st century. Many of the "truths" that we learned in library school are being challenged. Just one of the many questions: Should electronic information be archived? How much of it? Who should do the archiving? These are complex questions, and we need to develop a strategy together, as a profession.

By the end of my presidency, I hope to have made all of us aware of ALA and made ALA aware of us. I hope to see some real changes in how the membership is involved in the association.

Please give me the opportunity to serve as your president. Vote! Thank you! See you at http://www.katina.info!

\section{ACRL/Harvard Leadership Institute}

Academic libraries exist in a constantly changing environment with many new challenges and many available opportunities. New demands on academic libraries call for fundamental shifts in leadership knowhow. In response to these challenges, ACRL is collaborating with the Harvard Institutes for Higher Education to offer its popular ACRL/Harvard Leadership Institute.

At the ACRL/Harvard institute, you will be among your fellow leaders in academic librarianship. The institute is designed for directors of libraries and individuals in positions such as associate university librarian, assistant dean, vice president of information resources, university librarian, and college librarian. The institute would also be useful for individuals regularly involved in decision-making that affects the entire library operation and that involves other important relationships on campus.

Comments from past participants include:

"For the first time I have understood what I can find and see in myself to be a leader, and I know that I have excellent tools with which to do this. I will learn to burild on my strengths."
"I expected excellence and that is exactly what I found. The quality of the program, the faculty, and the participants made for an outstanding experience. Thank you for setting the tone and providing the space and time for open discussion and debate, laughter and learning."

"I think the mix and diversity of participants was integral to the success of the program. I enjoycd the chance to meet librarians from all types of academic institutions, and all parts of the country."

The 2002 ACRL/Harvard Leadership Institute will be held in Cambridge, Massachusetts, August 4-9, 2002. Registration materials and complete details about the institute are available on the Web at http:// www.gse.harvard edu/ ppe/. (Under programs, select "Higher Education," then scroll down to ACRL Leadership Institute.) Register early as spots will fill quickly. ACRL/ Harvard Leadership Institute alumni benefits include a subscription to an ongoing electronic list and annual alumni reunions at the ALA Midwinter Meeting.

Questions about this institute can be directed to acrl@ala.org; (800) 545-2433, ext. 2519 . 